P.O. Kuzema, Yu.M. Bolbukh, V.A. Tertykh

\title{
LUMINESCENT MATERIALS BASED ON ORGANIC SALTS PYROLYZED AT THE SILICA SURFACE
}

\author{
Chuiko Institute of Surface Chemistry of National Academy of Sciences of Ukraine \\ 17 General Naumov Str., Kyiv, 03164,Ukraine, E-mail: kuzema@isc.gov.ua
}

Recently, specific carbon-based nanomaterials (quantum dots, CDs) became highly attractive due to their low toxicity, good biocompatibility, chemical inertness, high photostability and fluorescence. Doping with some heteroatoms was found to be an effective approach to improve their luminescence. Besides, using the surface of silica as a support might facilitate the nanodots formation and expand the application area of carbon-silica composites. Recent advancements in synthesis of luminescent silica/CDs composites revealed great potential of such systems in bioimaging, sensor, as well as in solid-state lightning applications. Most of the synthetic methods are still relatively complex and costly. Here, the simple and inexpensive route to produce luminescent silica-based nanomaterials was used. The aim of this work was to study the luminescent properties of the materials obtained by pyrolysis of citric acid ureates at the nanosilica surface.

Fumed silica was used as a support material. The salts with various ratios of citric acid and urea were obtained either in aqueous or alcohol solution, and they were further deposited on silica surface. The resulting material was then heat treated at the temperature of up to $270{ }^{\circ} \mathrm{C}$, and the absorption and photoluminescence spectra for the samples obtained were collected and analyzed.

The results have shown that irrespective of the solvent used, both dried and pyrolyzed samples possess the luminescent properties, with quantum yield of photoluminescence being within 7-11\%. The change of the citric acid-to-urea ratio in aqueous solution within $1:(1 \div 3)$ doesn't affect the luminescent properties of dried samples, but further pyrolysis at $270{ }^{\circ} \mathrm{C}$ reduces the photoluminescence intensity. The solvent change to ethanol has an ambiguous influence on the luminescent properties of dried silica samples with different citric acid-to-urea ratio applied, however, further thermal treatment at $270{ }^{\circ} \mathrm{C}$ results in the formation of the materials with almost the same luminescence properties. Within the citric acid-to-urea ratios and the solvents used, as well as the heat treatment regimes applied, the variant with the 1:1 salt in the alcohol solution applied to the silica surface with further drying and heat treatment at $270{ }^{\circ} \mathrm{C}$ was found to be the most suitable.

Keywords: silica, citric acid, urea, carbon dots, thermal treatment; luminescent properties

\section{INTRODUCTION}

Carbon-based quantum dots (CDs) are relatively novel class of nanomaterials. From the time of their discovery in 2004, these materials attract great attention due to their low toxicity, good biocompatibility, chemical inertness, ease of functionalization, high photostability and fluorescence [1]. The materials on the basis of CDs are thus potential candidates to be used for instance as efficient nanoprobes, biovisualizers, and phosphors.

Quantum yield (QY) of photoluminescence (PL) for pristine CDs is quite low due to the presence of emission traps on the surface. To improve their brightness it is necessary to form a passivation layer on the surface. Also, higher PL QY is inherent to layered and more crystalline graphene-based CDs [2]. In the literature, a large number of methods for CDs producing are suggested (see, for instance, [3-12]). Most of those methods are not quite satisfactory because of the necessity to use costly equipment, the complexity of synthesis procedure, or low PL QY. Among the variety of methods to obtain highly luminescent CDs it is worth noting the hydrothermal synthesis of $\mathrm{N}$ - or N,S-doped CDs, using citric acid (C-source) and urea (N-source) or thiourea/L-cysteine (N,S-sources) $[11,12]$. The main advantage of this synthesis route is the cheapness as well as the ease of implementation and scaling, whereas PL QY of the CDs obtained reaches $70-78 \%$.

To enlarge the application area of CDs, further development of the synthetic routes for novel CD-based composites with improved PL characteristics is actual. In this respect, a promising direction is the formation of CDs with doped heteroatoms on the surface of oxide materials, in particular silica. Thus, recent 
advancements in synthesis and analysis of silica/CDs composites revealed great potential of such systems in bioimaging, sensor, as well as solid-state lightning applications, and, depending on the synthesis methods and the precursors used, it is possible already to achieve the PL QY from typically 5-14 up to $41 \%$ [13-20]. Most of the synthetic methods are still relatively complex and costly. Here, a simple and inexpensive route to produce luminescent silica-based nanomaterials was used. The aim of this work was to study the luminescent properties of the materials obtained by pyrolysis of citric acid ureate at the nanosilica surface as dependent on the citric acid-to-urea ratios and the solvents used, as well as the thermal treatment regimes applied.

\section{EXPERIMENTAL}

Fumed silica with a specific surface area of $300 \mathrm{~m}^{2} / \mathrm{g}$ (A-300, Kalush, Ukraine) was used as a support material. The salts with various molar ratios of citric acid and urea (1:1, 1:1.5, and 1:3) were obtained either in aqueous or alcohol solution, and they were further applied to silica surface by dropwise addition of the salt solution to a silica powder. The obtained powder-like materials were dried and then thermally treated at the temperature of up to $270{ }^{\circ} \mathrm{C}$. After that, the absorption and PL emission spectra for dried and pyrolyzed samples were collected and analyzed.

The typical procedure of synthesis was as follows. $0.8 \mathrm{~g}$ of citric acid and $0.25 \mathrm{~g}$ of urea (both are of chemical purity grade) were added into a glass with $23.5 \mathrm{~mL}$ of distilled water or ethanol (96\% v/v pure) and then the mixture was stirred with a magnetic stirrer until the complete dissolution of the reagents. After that, an aliquot of $5 \mathrm{~mL}$ was taken from the solution of citric acid monoureate for further use. $10 \mathrm{~g}$ of silica A-300 were placed into the 3-necked glass reactor and $5 \mathrm{~mL}$ of either aqueous or ethanol solutions of citric acid ureate were added dropwise at high agitation speed. After all the reagents were added, the mixture was agitated at the same speed for additional several hours. The obtained powder-like material was taken from the reactor and heat treated at $105^{\circ} \mathrm{C}$ for $2 \mathrm{~h}$ (drying) and then at $270^{\circ} \mathrm{C}$ for $2 \mathrm{~h}$ (carbonization).

The crystallinity of citric acid, urea as well as the crystallized pure citric acid monoureate was studied by means of X-ray diffraction using a DRON-3 diffractometer.
Room temperature UV-Vis absorption spectra of solid samples were recorded using a V-660 JASCO spectrophotometer, and emission spectra were obtained with a Photon Technology International spectrofluorimeter equipped with a continuous wave xenon arc (Xe-arc) lamp as a light source.

\section{RESULTS AND DISCUSSION}

Fig. 1 shows the XRD spectra for powdered samples of urea (1), citric acid (2), and the product of their interaction (3), obtained by crystallization from aqueous solution with molar ratio urea : citric acid $=1: 1$.

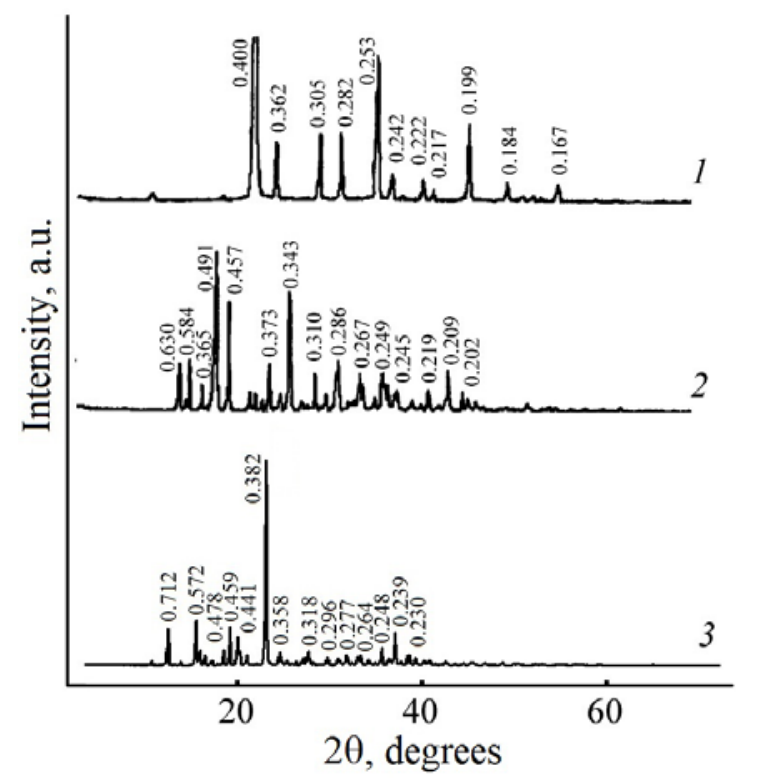

Fig. 1. X-ray diffraction patterns for powdered samples: 1 - urea, 2 - citric acid; 3 - salt of urea and citric acid $(1: 1)$

The comparison of these spectra shows that the product of citric acid reaction with urea, condensed from aqueous solution, is a polycrystalline substance having individual reflexes (interplanar spacing values) which are not inherent to the initial reagents. This fact confirms that the product obtained (citric acid monoureate) is an individual substance.

Citric acid monoureate (the salt $1: 1$ ), crystallized from aqueous solution, absorbs the irradiation at the wavelength region of up to $500 \mathrm{~nm}$ with one distinct maximum at $200 \mathrm{~nm}$ (Fig. $2 a$ ). At the same time, this salt, condensed at the fumed silica surface from the aqueous solution, after heat treatment at $105^{\circ} \mathrm{C}$ has another single distinct maximum of absorption at about $340 \mathrm{~nm} \quad$ (Fig. 2 c). Further thermal 
treatment of the sample at $270{ }^{\circ} \mathrm{C}$ causes a shift of the first absorption maximum into the region of $234 \mathrm{~m}$. The presence of the peaks at 234 and $350 \mathrm{~nm}$ may be related to $p$-electron transitions in the formed oxygen-containing carbonaceous
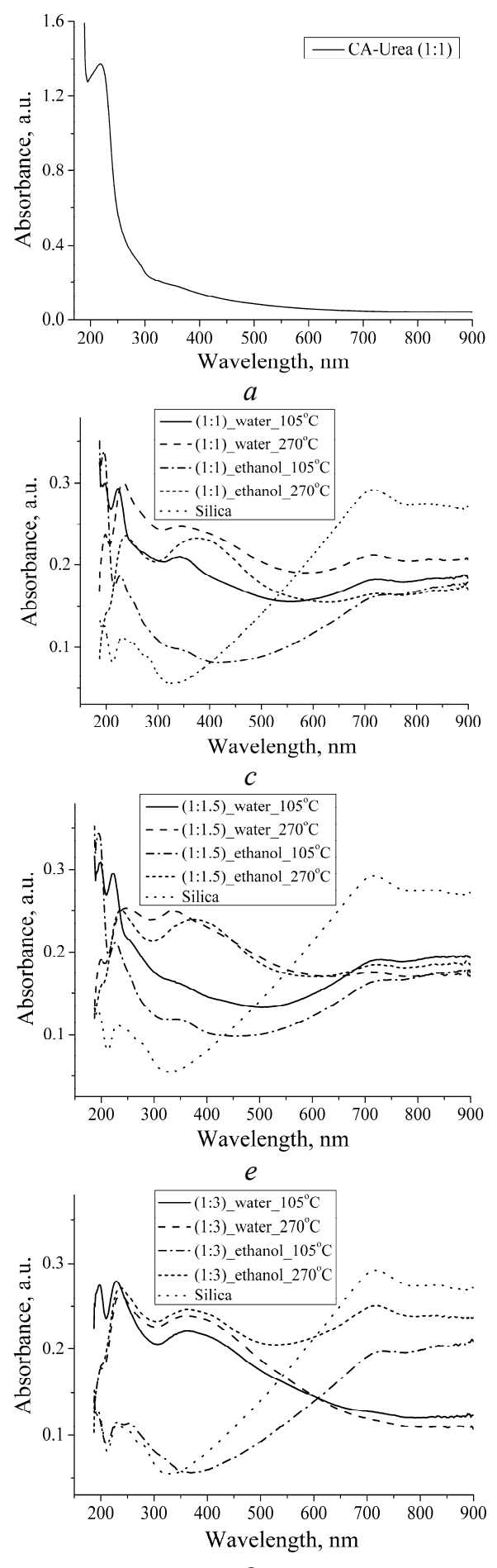

$g$ structures. The first absorption peak is due to $\pi \rightarrow \pi^{*}$ transition in $\mathrm{C}=\mathrm{C}$ bond, whereas in the second case the absorption occurs owing to $n \rightarrow \pi^{*}$ transition in $\mathrm{C}=\mathrm{O}$ bond [12].
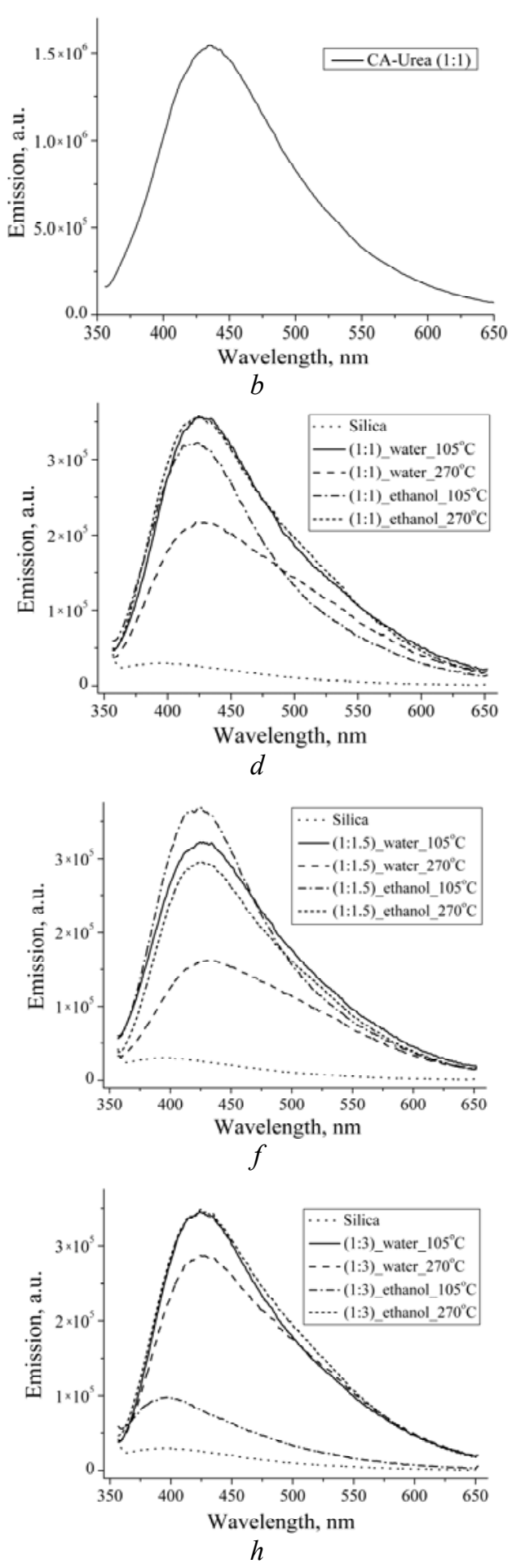

Fig. 2. Absorption (left) and PL emission (right) spectra (excitation wavelength is $340 \mathrm{~nm}$ ) for the samples: the salt of citric acid (CA) and urea $(1: 1)(a, b)$; fumed silica with applied to the surface salt of citric acid-to-urea ratio $1: 1(c, d), 1: 1.5(e, f)$, and $1: 3(g, h)$ 
It should be noted that the solvent change from water to ethanol practically does not effect on the location of the absorption maxima in the case of silica dried at $105^{\circ} \mathrm{C}$ (the intensity is somewhat less), however, it affects the width and location of the second peak maximum after the treatment at $270{ }^{\circ} \mathrm{C}$. The latter becomes wider and has the maximum at $380 \mathrm{~nm}$. This may be attributed to the presence of additional (ether) bonds because of ethanol participation in etherification reactions. In both cases when different solvents are used, the thermal treatment at $270{ }^{\circ} \mathrm{C}$ promotes some rising of absorption intensity in the above-mentioned region.

The situation similar to the described above is observed when the citric acid-to-urea molar ratio is changed to $1: 1.5$ (Fig. $2 e$ ), and only in the case of the 1:3 ratio the profile of the absorption curve within the $200-450 \mathrm{~nm}$ region is identical for heat treated at $270{ }^{\circ} \mathrm{C}$ samples irrespective of the solvent used (Fig. $2 \mathrm{~g}$ ). Upon this, the citric acid-to-urea molar ratio, as well as the solvent nature affects insignificantly the absorbance of these samples within the given region.

Taking into account the peculiarities of absorption by the samples, excitation UV irradiation with maximum at $\lambda=340 \mathrm{~nm}$ was chosen. The PL emission spectrum of the citric acid monoureate sample is shown in Fig. $2 b$. As one can see, the maximum of PL intensity is located at $430 \mathrm{~nm}$ (blue light), i.e., in comparison with the excitation $\lambda_{\max }$, the shift of the emission $\lambda_{\max }$ into the longer wave region by $90 \mathrm{~nm}$ takes place. Upon this, the sample demonstrates relatively high PL intensity. In the case when this salt is condensed from the aqueous solution on the surface of fumed silica (which itself doesn't possess the luminescent properties) after the treatment at $105^{\circ} \mathrm{C}$, one can also observe the PL with $\lambda_{\max }$ at $430 \mathrm{~nm}$ (Fig. $2 d$ ). This PL is less pronounced than that in the case of the pure salt, and the further thermal heat of the sample at $270{ }^{\circ} \mathrm{C}$ leads to a more essential decrease in the PL intensity. When the water solvent was changed to ethanol, the essential changes in PL properties of dried at $105^{\circ} \mathrm{C}$ silica with applied citric acid monoureate were not observed (except that PL intensity slightly decreases), however, further sample treatment at $270{ }^{\circ} \mathrm{C}$ increases its PL properties and closes to those typical for the dried at $105^{\circ} \mathrm{C}$ silica with citric acid monoureate applied from aqueous solution.
The change in citric acid-to-urea ratio from $1: 1$ to $1: 1.5$ does not change the PL properties of dried silica with applied salt from aqueous solution, as well as the tendency to essential PL decrease under further treatment at $270{ }^{\circ} \mathrm{C}$ (Fig. 2f). When ethanol solvent was used, the PL of dried sample is somewhat higher than that for the sample with applied 1:1 salt, and further heat treatment at $270{ }^{\circ} \mathrm{C}$ decreases the PL properties making them somewhat worse than those in the case of heat treated at $270{ }^{\circ} \mathrm{C}$ silica with applied 1:1 salt from ethanol solution.

When the salt with citric acid-to-urea ratio 1:3 was used (Fig. $2 h$ ), no change was observed in PL properties of the dried at $105^{\circ} \mathrm{C}$ silica in the case of aqueous solution. Further heat treatment of such silica at $270{ }^{\circ} \mathrm{C}$ also reduces the luminescence, however, not so significantly as in the case of the $1: 1$ and 1:1.5 salts. Solvent change to ethanol leads to PL properties worsening as compared to analogues with $1: 1$ and 1:1.5 salts. However, further thermal treatment of such silica increases its PL properties that become close to those for the case of $1: 1$ and $1: 1.5$ salts.

\section{CONCLUSION}

Solid products of thermolysis of fumed silicas with citric acid ureates, deposited on the surface from aqueous or alcohol solutions, possess the luminescent properties.

The change in the citric acid-to-urea ratio within the range of $1: 1,1: 1.5$, and 1:3 does not effect on the PL intensity for the dried at $105^{\circ} \mathrm{C}$ silica with the salt applied from aqueous solutions, and further heat treatment at $270{ }^{\circ} \mathrm{C}$ reduces the PL intensity.

The solvent change from water to ethanol has an ambiguous effect on the PL properties of dried silica with various citric acid-to-urea ratios applied, however, subsequent heat treatment at $270{ }^{\circ} \mathrm{C}$ leads to formation of materials with similar PL properties irrespective of these ratios.

Within the citric acid-to-urea ratios and the solvents used, as well as the thermal treatment regimes applied, the variant with the $1: 1$ salt deposited on silica surface from the alcohol solution with further drying and heat treatment at $270{ }^{\circ} \mathrm{C}$ was found to be the most suitable, however, the PL intensity is still not so high generally (the quantum yield of photoluminescence is about $11 \%$ ), suggesting the necessity of further research aimed at 
optimization of structure/composition and PL properties of carbon-silica composites.

\section{ACKNOWLEDGEMENT}

The authors are grateful to Agnieszka Lipke from the Faculty of Chemistry of Maria CurieSkłodowska University (Poland) for the assistance in the spectrofluorimetric analysis and quantum yield determination for the samples of silica-based nanocomposites.

\title{
Люмінесцентні матеріали на основі органічних солей, піролізованих на поверхні кремнезему
}

\author{
П.О. Кузема, Ю.М. Больбух, В.А. Тьортих \\ Інститут хімії поверхні ім. О.О. Чуйка Національної академії наук Украӥни \\ вул. Генерала Наумова, 17, Київ, 03164, Україна, kuzета@isc.gov.иа
}

\begin{abstract}
Останнім часом широку увагу дослідників привертає особливий різновид вуглецевих наноматеріалів вуглецеві наноточки (ВНT), завдяки їх низькій токсичності, гарній біосумісності, хімічній інертності, високій фотостабільності та люмінесцениіі. Встановлено, що допування деякими гетероатомами $\epsilon$ ефективним підходом для поліпшення люмінесценції таких матеріалів. Крім того, використання поверхні кремнезему як носія може промотувати синтез ВНТ і розширити сферу застосування кремнезем-вуглецевих композитів. Останні досягнення в області синтезу люмінесцентних композитів на основі кремнезему та ВНТ показали високий потенціал таких систем у процесах біовізуалізації, сенсорики та твердотільного освітлення. Проте більшість методів синтезу таких матеріалів все ще залишаються відносно складними та коштовними. В даній роботі було використано простий та недорогий спосіб одержання люмінесиентних наноматеріалів на основі кремнезему. Мета роботи полягала у вивченні люмінесиентних властивостей матеріалів, одержаних піролізом уратів циттринової кислоти на поверхні кремнезему.

Як матеріал-носій використовували пірогенний кремнезем. Спочатку готували водні або спиртові розчини солей з різним співвідношенням циттинової кислоти та сечовини, а потім проводили осадження цих солей на поверхню кремнезему. Одержаний матеріал піддавали термічній обробизі за температури до $270{ }^{\circ} \mathrm{C}$, після чого проводили реєстраџฺію і аналіз спектрів поглинання та фотолюмінесцениії ичих зразків.

Результати показали, щзо, незалежно від використаного розчинника, як висушені, так $i$ піролізовані зразки проявляють люмінесиентні властивості, причому квантовий вихід люмінесценції знаходиться 6 межах 7-11\%. Заміна співвідношення циитринова кислота:сечовина в діапазоні значень $1:(1 \div 3)$ не впливає на люмінесцентні властивості висушених зразків, однак їх подальша термообробка при $270{ }^{\circ} \mathrm{C}$ призводить до зниження інтенсивності люмінесценції. Заміна розчинника з води на етиловий спирт неоднозначно впливає на люмінесиентні властивості висушених зразків кремнезему з нанесеними солями у різних співвідношеннях циитринова кислота:сечовина. Проте, подальша термообробка при $270{ }^{\circ} \mathrm{C}$ приводить до того, щзо, незалежно від изих співвідношень, такі кремнеземи володіють приблизно однаковими люмінесцентними властивостями. Серед використаних співвідношень цитринова кислота:сечовина, розчинників $і$ варіантів термічної обробки, найбільш прийнятним є варіант нанесення на кремнезем солі 1:1 із спиртових розчинів 3 подальшою сушкою і термічною обробкою при $270{ }^{\circ} \mathrm{C}$.
\end{abstract}

Ключові слова: кремнезем, ичтринова кислота, сечовина, вуглецеві точки, термічна обробка, люмінесиентні властивості 


\title{
Люминесцентные материалы на основе органических солей, пиролизованных на поверхности кремнезема
}

\author{
П.А. Кузема, Ю.Н. Больбух, В.А. Тертых
}

\author{
Институт химии поверхности им. А.А. Чуйка Национальной академии наук Украинь \\ ул. Генерала Наумова, 17, Киев, 03164, Украина, kuzета@isc.gov.ua
}

В последнее время широкое внимание исследователей привлекает особый вид наноматериалов углеродные наноточки (УНТ), благодаря их низкой токсичности, хорошей биосовместимости, химической инертности, высокой фотостабильности и люминесценции. Установлено, что допирование некоторыми гетероатомами является эффективным подходом для улучшения люминесценичи таких материалов. Кроме того, использование поверхности кремнезема как носителя может облегчать синтез УНТ и расширить сферу применения кремнезем-углеродных композитов. Последние достижения в области синтеза люминесцентных композитов на основе кремнезема и УНТ показали высокий потенциал таких систем в процессах биовизуализации, сенсорики и твердотельного освещения. Однако большинство методов синтеза таких материалов все еще остаются относительно сложными и дорогостоящими. В данной работе был использован простой и недорогой способ получения люминесцентных наноматериалов на основе кремнезема. Цель работы заключалась в изучении люминесцентных свойств композитов, полученных пиролизом уреатов лимонной кислоты на поверхности кремнезема.

Как материал-носитель использовали пирогенный кремнезем. Сначала готовили водные или спиртовые растворы солей с различным соотночением лимонной кислоты и мочевины, а затем проводили осаждение этих солей на поверхность кремнезема. Полученный материал подвергали термической обработке при температуре до $270{ }^{\circ} \mathrm{C}$, после чего проводили регистращию и анализ спектров поглощения $u$ фотолюминесиенциии этих образцов.

Результаты показали, что, независимо от использованного растворителя, как высуценные, так и пиролизованные образцы проявляют люминесцентные свойства, причем квантовый выход люминесценции находится в пределах 7-11\%. Замена соотношения лимонная кислота:мочевина в диапазоне значений

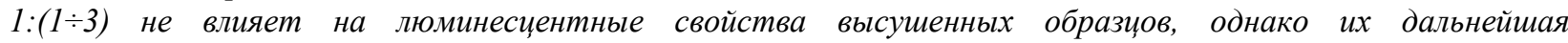
термообработка при $270{ }^{\circ}$ С приводит к снижению интенсивности люминесценции. Замена растворителя с воды на этиловый спирт неоднозначно влияет на люминесцентные свойства высушенных образиов кремнезема с нанесенными солями в разных соотношениях лимонная кислота:мочевина. Однако дальнейшая термообработка при $270{ }^{\circ} \mathrm{C}$ приводит к тому, что, независимо от этих соотношений, такие кремнеземь обладают примерно одинаковыми люминесцентными свойствами. Среди использованных соотношений лимонная кислота:мочевина, растворителей и вариантов термической обработки, наиболее приемлемым является вариант нанесения на кремнезем соли 1:1 из спиртовых растворов с последующей сушкой $и$ термической обработкой при $270{ }^{\circ} \mathrm{C}$.

Ключевые слова: кремнезем, лимонная кислота, мочевина, углеродные точки, термическая обработка, люминесиентные свойства

\section{REFERENCES}

1. Yang Z., Li Z., Xu M., Ma Y., Zhang J., Su Y., Gao F., Wei H., Zhang L. Controllable synthesis of fluorescent carbon dots and their detection application as nanoprobes. Nano-Micro Lett. 2013. 5(4): 247.

2. Zheng X.T., Ananthanarayanan A., Luo K.Q., Chen P. Glowing graphene quantum dots and carbon dots: properties, syntheses, and biological applications. Small. 2015. 11(14): 1620.

3. Du W., Xu X., Hao H., Liu R., Zhang D., Gao F., Lu Q. Green synthesis of fluorescent carbon quantum dots and carbon spheres from pericarp. Sci. China Chem. 2015. 58(5): 863.

4. Qian Z., Shan X., Chai L., Ma J., Chen J., Feng H. Si-doped carbon quantum dots: a facile and general preparation strategy, bioimaging application, and multifunctional sensor. ACS Appl. Mater. Interfaces. 2014. 6(9): 6797.

5. Anilkumar P., Wang X., Cao L., Sahu S., Liu J.-H., Wang P., Korch K., Tackett K.N., Parenzan A., Sun Y.-P. Toward quantitatively fluorescent carbon-based «quantum» dots. Nanoscale. 2011. 3(5): 2023. 
6. Yang C., Thomsen R.P., Ogaki R., Kjems J., Teo B.M. Ultrastable green fluorescence carbon dots with high quantum yield for bioimaging and use as theranostic carriers. J. Mater. Chem. B. 2015. 3: 4577.

7. Cao L., Yang S-T., Wang X., Luo P.G., Liu, J.-H. Sahu S., Liu Y., Sun Y.-P. Competitive performance of carbon "quantum" dots in optical bioimaging. Theranostics. 2012. 2(3): 295.

8. Li X., Zhang S., Kulinich S.A., Liu Y., Zeng H. Engineering surface states of carbon dots to achieve controllable luminescence for solid-luminescent composites and sensitive $\mathrm{Be}^{2+}$ detection. Sci. Rep. 2014. 4: 4976.

9. Hu L., Sun Y., Li S., Wang X., Hu K., Wang L., Liang X., Wu Y. Multifunctional carbon dots with high quantum yield for imaging and gene delivery. Carbon. 2014. 67: 508.

10. Wei W., Xu C., Wu L., Wang J., Ren J., Qu X. Non-enzymatic-browning-reaction: a versatile route for production of nitrogen-doped carbon dots with tunable multicolor luminescent display. Sci. Rep. 2014. 4: 3564.

11. Dong Y., Pang H., Yang H.B., Guo C., Shao J., Chi Y., Li C.M., Yu T. Carbon-based dots co-doped with nitrogen and sulfur for high quantum yield and excitation-independent emission. Ang. Chem. Int. Ed. 2013. 52(30): 1 .

12. Qu D., Zheng M., Du P., Zhou Y., Zhang L., Li D., Tan H., Zhao Z., Xied Z., Sun Z. Highly luminescent S, N co-doped graphene quantum dots with broad visible absorption bands for visible light photocatalysts. Nanoscale. 2013. 5: 12272.

13. Kang M.S., Singh R.K., Kim T.H., Kim J.H., Patel K.D., Kim H.W. Optical imaging and anticancer chemotherapy through carbon dot created hollow mesoporous silica nanoparticles. Acta Biomater. 2017. 55: 466.

14. Wang Z., Xu C., Lu Y., Wu F., Ye G., Wei G., Sun T., Chen J. Visualization of adsorption: luminescent mesoporous silica-carbon dots composite for rapid and selective removal of U(VI) and in situ monitoring the adsorption behavior. ACS Appl. Mater. Interfaces. 2017. 9(8): 7392.

15. Xiang G., Ren Y., Zhang H., Fan H., Jiang X., He L., Zhao W. Carbon dots based dual-emission silica nanoparticles as ratiometric fluorescent probe for chromium speciation analysis in water samples. Can. J. Chem. 2018. 96(1): 72.

16. Suzuki K., Malfatti L., Takahashi M., Carboni D., Messina F., Tokudome Y., Takemoto M., Innocenzi P. Design of carbon dots photoluminescence through organo-functional silane grafting for solid-state emitting devices. Sci. Rep. 2017. 7: 5469.

17. Nelson D.K., Razbirin B.S., Starukhi A.N., Eurov D.A., Kurdyukov D.A., Stovpiaga E.Yu., Golubev V.G. Photoluminescence of carbon dots from mesoporous silica. Opt. Mater. 2016. 59: 28.

18. Tian Y., Ran Z., Yang W. Carbon dot-silica composite nanoparticle: an excitation-independent fluorescence material with tunable fluorescence. RSC Adv. 2017. 7(69): 43839.

19. Guo Z., Zhu Zh., Zhang X., Chen Y. Facile synthesis of blue-emitting carbon dots@mesoporous silica composite spheres. Solid State Sci. 2018. 76: 100.

20. Wang J., Zhang F., Wang Y., Yang Y., Liu X. Efficient resistance against solid-state quenching of carbon dots towards white light emitting diodes by physical embedding into silica. Carbon. 2018. 126: 426. 